\title{
The Role of Non-Governmental Organization in Preventing Violent Extremism in Indonesia: The Case of Wahid Foundation
}

\author{
M Z Achsin ${ }^{1}$, Seniwati ${ }^{2}$, R Effendi ${ }^{3}$, Triyanto ${ }^{4}$, M Y S J Bello ${ }^{5}$, N A Ninggara ${ }^{6}$, S Rafifah $^{7}$, \\ S N Gularso ${ }^{8}$ \\ ${ }^{1}$ Universitas Brawijaya, Malang, ${ }^{2}$ Universitas Hasanuddin, Makassar, ${ }^{3}$ Universitas Pendidikan \\ Indonesia, Bandung, ${ }^{4}$ Universitas Sebelas Maret, Surakarta, ${ }^{5,6,7,8}$ Universitas Brawijaya, \\ Malang \\ 1'muhaimin.zul@ub.ac.id, ${ }^{2}$ seniwati_2006@yahoo.co.id, ${ }^{3}$ reffendi09@upi.edu, \\ 4try uns@yahoo.com, ${ }^{5}$ mariabello2409@gmail.com, ${ }^{6}$ nadya.ninggara@gmail.com \\ ${ }^{7}$ salmarzulfikar@gmail.com, ${ }^{8}$ sofii.nadiaa@gmail.com
}

\begin{abstract}
Non-governmental organization holds a vibrant role of preventing violent extremism in the present climate than ever before. While the government focuses on tackling the issue at the macro level, NGOs tend to put more attention at the micro level that represents a more localized approach. Wahid Foundation is among the numerous NGOs that have concerns in violent extremism prevention. Considering this, the foundation has conducted several programs such as Desa Damai, which focuses on economic empowerment of the villagers and socialization, and Sekolah Damai, which focuses on creating a tolerant environment within the school to prevent extremism. These programs are particularly done in Java. Therefore, this research focuses on analyzing Wahid Foundation's role in preventing violent extremism through these two programs. This research is a qualitative descriptive research, which collects the data from both primary and secondary sources that are obtained through interview and literature review. The method of analysis used is interpretative method. The result of the research shows that efforts made by Wahid Foundation in preventing violent extremism is quite effective considering the programs serve its focus of preventing violent extremism with a specific target, namely local villages and schools, but at the some points the economic dimension as the effect of the program more condensed than constructing society as the early warning system to tackle radicalization. However, Wahid Foundation is facing two main problems. First, is the resistance from certain community towards their program. Second, the foundation is facing challenges of expanding their capability of reaching people outside Java, as violent extremism issues are not limited to Java alone. Several findings are also shown that the villages which became pilot project were not vulnerable to the extremist recruitment.
\end{abstract}

Keywords: Preventing Violent Extremism, Non-Governmental Organization, Wahid Foundation 


\section{INTRODUCTION}

Terrorism is a global issue that has been seen as a threat to humanity, thus the responsibility of preventing and countering terrorism should not be left to the government alone. Over the past years, the role of society in terrorism prevention becomes even more considered. This is due to how much terrorism, that often uses violence extremism, has affected the society the most.

Historically, the 21 st century terrorism has taken a different model of terrorism than what it was known before. Terrorism used to be done by separatist group as an act of rebellion and resistance towards the status quo. However, the September 11 attack in the United States of America, terrorism has been much attributed to certain ideologies of extremism. In Indonesia, terrorism with violence extremism has become a major national issue. Upon the September 11 tragedy, Indonesia has faced many terrorist attacks, mainly bombings. Some of the known attacks are the first and second Bali Bombings, the bombings in various strategic places in Jakarta (namely JW Marriot Hotel and an embassy), etcetera. There was the Surabaya Church Bombings as well that was done by a family. This alerts the society that ideology-based terrorism has spread widely in Indonesia.

Considering the urgent nature of this issue, Indonesian government has created UU No. 5 of Year 2018, which is the amendment of the previous rule, UU No. 1 of Year 2002. The amendment is the legal base of Badan Nasional Penanggulangan Terorisme (the National Agency for Combating Terrorism) which was established to create policies and do the means in order to prevent and counter any form of terrorism. Other than BNPT, institutions such as Detachment 88, the Ministry of Communication and Informatics and the Indonesian National Armed Forces have their own role in this issue based on their mandate.

Beside the state apparatus, society could take part in violent extremism prevention. One form of society's involvement is nongovernmental organization that works together with government agencies. Society's involvement, in preventing or handling terrorism is considered to be very important. As the society realizes that terrorism contributes destructively to human civilization, there is lesser chance for them to be influenced by the extreme ideologies. Moreover, society's rejection will provide less space for terrorism to grow. In achieving this, socialization among people becomes a much more attractive strategy than vertical socialization from government to the people.

Several studies have shown that the important causal factor of people's decision to join extremist groups (religion-based) is the ideological injection or brain washing or doctrine[1] [4]. Moreover, the doctrine can easily penetrate into individual's life when condition of saturation point happened. Saturation point is derived from personal problems such as boredom at domestic life which compel individuals to search for a deeper understanding of religion that would provide them meaningful life than before [5]. Other works explain terrorism - extremism through the lens of economic dimension [6], [7], social - cultural condition [8], [9] and cyber spaces [10]-[12].

In order to prevent saturation point from occurring in an individual life, social bond becomes an important supporting system particularly to prevent extremism doctrine, both offline and online. Therefore, the role of non-governmental organizations to support social bonds become more important. Several works has also explained the importance of civil society organization's role in PVE/CVE [13], [14].

One of the NGOs that focus on preventing violent extremism in Indonesia is Wahid Foundation. It was founded back in 2004 by the Republic of Indonesia's former president, Abdurrahman Wahid, under the name of Wahid Institute. The main purpose of this foundation 
is to spread the ideas of President Wahid, namely Islam as a religion of peace that respects and accepts diversity, as well as spreading democratic values in Indonesia. As this organization is expected to grow bigger, the name then transformed into Wahid Foundation. Therefore, this research poses a question; how does Wahid foundation contribute to violent extremism prevention in society through the programs of Sekolah Damai and Desa Damai?

\section{RESEARCH METHOD}

This research uses qualitative approach, for it enables the researcher to investigate matters which appear from individual and social issues. Along with this, the researchers will use inductive data interpretation as the chosen analysis technique. The purpose of this research is to act as a basic research which becomes useful in developing human's fundamental knowledge of the social world. Therefore, this research is conducted as a descriptive research.

In this context, in order to describe the chosen social phenomenon, the researcher will collect data from open-ended interview with a primary source as well as secondary source. The subject of the interview, in particular, is the staff of Wahid Foundation. Meanwhile, the secondary source is both online and offline research. The aim of this descriptive research is to describe the role of Wahid Foundation in preventing violent extremism within the society. Furthermore, the concept that is used as an analytical tool is "the resilient community". The way it is applied into Wahid Foundation's programs, namely Sekolah Damai and Desa Damai, is the extent of this particular research focus.

\section{RESULTS AND DISCUSSSION}

Aforementioned, the concept of resilient community roots back to the overall capacity of a community in preventing its members from engaging in violent extremism. Stephens posits that a resilient community surpasses the concept of specific intervention, in a sense that acts of prevention should not be centralized on certain elements in society whilst disregarding the other elements. The basic assumption that is accommodated in this concept is that the quality of social connections and relationships within a community are becoming important to prevent community members from being drawn into extremism. In order to achieve such good quality of social relationship, every element in the community therefore needs to be managed. There are three types of relationships that can be observed in a resilient community. Stephens explains them as the relationship within a community (social bonding), between communities (social binding), as well as between communities and institutions (social linking)[15].

In the context of Wahid Foundation, it has designed a particular program that targets an important demographic in community which is the youth. The program is named Sekolah Damai, conducted in Indonesian public high schools that are located in East Java, Central Java, and West Java. As of now, Wahid Foundation has worked to initiate this program in sixty public high schools, however only twenty schools that have been granted the official name and status of Sekolah Damai (Peace School). The decision to use public high schools for Sekolah Damai's implementation is arguably strategic due to two main reasons. First, youth is an integral part of the community that can easily be mobilized. Therefore, ensuring their access to the concept of tolerance and its application becomes important. Youth mobilization in a resilient community is ideally rooted in peaceful and tolerant means, not in violent and extremism. Second, public high schools in Indonesia are seen as the strategic place where people of different communities are positioned to interact with one another. Public schools therefore become a larger community which accommodates youths from smaller communities 
of culture, religion, race, and economic background in Indonesia. All three relationships that are ought to be observed in a resilient community can be identified in this social environment.

According to Libasut Taqwa, a staff of Wahid Foundation who is the primary source of this research, three important criteria are used to see whether or not a public high school is fit to be officially recognized as Sekolah Damai. First, the high school must have proper policy regarding extremism prevention. This is marked as the initiation of a high school into the program of Sekolah Damai because Wahid Foundation believed that the program will only succeed if there is an active participation from the school boards. This first criteria can be identified as social linking, particularly in this case the school boards of the public high schools are the official representatives of state apparatus considering public high schools are managed under the Ministry of Education. Therefore, it can be derived that the Ministry of Education has an influence in the policy making done by the boards in public schools. If elements of extremism prevention are institutionalized in public high schools, there is a high chance that the state, through its apparatus, is attempting to create a social relationship with its community that is rooted in peaceful values for the development of a resilient community.

Once violent extremism prevention is established institutionally in public high schools, the second criteria that has to be fulfilled is ensuring a peaceful and tolerant environment in the school. Particularly for this criteria, social binding between communities can be identified. Libasut Taqwa describes a peaceful and tolerant environment as a condition where members of the school, whether it would be teachers or students, to actively participate in campaigns and acts towards tolerance. It can be expressed in the form of dialogues, field trips to places of worship, or culture training where respect and tolerance towards differences are taught. Through these activities, school members especially the students have the opportunity to discuss and learn about tolerance in civil way by interacting with people from various smaller communities. Students are being taught not to weaponize their differences against each other and see it as a threat against their own values. It becomes difficult for the students not to interact with one another because they are bounded by the same thing, which is their place in the high school as the bigger community, and linked with the policies of the state that supports violent extremism prevention.

Lastly, the presence of the public high school as a bigger community where various smaller social communities come together must always be nurtured and maintained. According to Libasut Taqwa, this is done through the quality of the teaching-learning process that occurs within the school. The main concept of this criteria is that the community may only develop into a resilient community if the values of tolerance and peace are integrated in all elements of human interaction. As the highest level of mandatory education in Indonesia, high school becomes the last destination where youths learn the basic necessary knowledge of the world and its societies. Therefore, integration of tolerance and peace values into the learning materials of the students are seen to be important. Wahid Foundation believes that for every course that is taught in high school, the students must also be equipped with the awareness and understanding of how those knowledges can be used for peaceful means. This way, the youths can be moved or even take the initiative of contributing to the building of a resilient community in a constructive way, instead of being destructive. Wahid Foundation acknowledges how easy it is for youths to be mobilized into using their knowledge for wrongful means, therefore this last criterion is seen as a way to seal the whole program of Sekolah Damai into completion. However, the foundation still lacks the tools to evaluate whether or not the program is targeting the right audience.

Another core program of Wahid Foundation is Desa Damai. This program has become one of the most important projects of Wahid Foundation. Initially, this program was 
implemented in thirty villages, however currently there are approximately ten villages that have succeeded as Desa Damai. This project is conducted in various parts of Java as well. Women empowerment is the focus of this program. Wahid Foundation uses economic means to empower women. In line with this, Wahid Foundation created Koperasi Cinta Damai, a union that provides loans, training, and financial counselling for women. These programs has enabled women to have their own business.

In a way, this program has developed a sense of resilience within the village community towards violent extremism. As known, in certain conditions, the spread of terrorism as an ideology began with the belief that they will get something from heaven by doing sacrificing for their ideology. Through economic empowerment, people will be less likely to believe this idea because they will be more civilized and have the means to act as peace agents for their own community. The main idea behind this agenda, beside pluralism and tolerance notions, is to keep the women occupied with constructive activities.

Furthermore, this economic approach could also be considered as social linking and social bonding processes. Social bonding process exists through the existence of the union, which has created a platform for the people within the society to interact more, thus creating a stronger bond among them. When people within the community have a strong bond, the probability of them getting ideologically radicalized will decrease because the society has a strong filter. However, the use of economic approach rather than a general educational approach to counter ideology and tackle extremism can be categorized as a selective approach, particularly the type that will produce outcomes that are narrower and much more specific than the idea of PVE itself. In this case, Desa Damai can be seen as a program of economic empowerment similar to business program rather than a social program aimed to tackle violent extremism. From this perspective, Desa Damai does not quite fulfill the concept of resilient community which tend to avoid selective approaches in dealing with violent extremism prevention.

However, there are still some challenges faced by Wahid Foundation while implementing these programs. With Desa Damai, Wahid Foundation do not have full back up of the village during apparatus changes. This is where the social linking finds challenge, because there is no guarantee that the new apparatus is in favor of the program. It threatens the sustainability of this program for it mainly relies on the cooperation and mutual understanding between facilitator of Wahid Foundation and the village apparatus in order to build a resilient community. Moreover, the selection of villages that become the pilot projects are also questionable because the selected villages are relatively in harmony, for instance villages in Singosari and Batu.

Other challenges faced by Wahid Foundation in doing both of these programs are the effectiveness as well as the financial burden. As written before, not all villages and schools that were intially meant to be Desa Damai and Sekolah Damai have successfully been declared as Desa Damai and Sekolah Damai. Rejection from society is the main reason why this initiative has not come into success. The financial burden also limits Wahid Foundation to do these programs only in Java, while violent extremism cases are not limited in Java alone. The limitation of program is based on funding from donor. Moreover, the sustainability of this program

\section{CONCLUSIONS}

Wahid Foundation's effort in violent extremism prevention through building resilient communities is considered to be quite successful, despite some critical points and challenges 
this institution has to face. By engaging with youth and women through Sekolah Damai and Desa Damai, it shows that they are trying to support social bonding, social linking and social binding processes. In Sekolah Damai program, tolerance, pluralism and awareness are taught to the students in order for them to understand the danger of extremism doctrine, meanwhile in

Desa Damai, the economic dimension of women empowerment is emphasized.

\section{REFERENCES}

[1] I. Chalmers, "Countering Violent Extremism in Indonesia : Bringing Back the Jihadists Countering Violent Extremism in Indonesia : Bringing Back the," Asian Stud. Rev., vol. 41, no. 3, pp. 331-351, 2017.

[2] A. Pedahzur, Root Causes of Suicide Terrorism. 2006.

[3] M. H. Becker, "Studies in Conflict \& Terrorism When Extremists Become Violent : Examining the Association Between Social Control, Social Learning, and Engagement in Violent Extremism When Extremists Become Violent : Examining the Association Between Social Control , S," Stud. Confl. Terror., vol. 0, no. 0, pp. 1-21, 2019.

[4] K. Ramakrishna, T. Power, and M. Mindset, Islamist Terrorism and Militancy in Indonesia. .

[5] A. Satria, P. Putri, N. Sari, and R. Adriana, "The Current State of Terrorism in Indonesia : Vulnerable Groups , Networks , and Responses," pp. 0-18, 2018.

[6] Alan B. Krueger, What Makes a Terrorist: Economics and the Roots of Terrorism. Princenton University Press, 2018.

[7] R. A. P. Gary S. Becker, Uncommon Sense_Economic Insights, from Marriage to Terrorism. University Of Chicago Press, 2019.

[8] "Ethnicity and Politics in Contextualising Far Right and Islamist Extremism," vol. 11, no. 3, pp. 54-61, 2019.

[9] M. Z. Achsin, "Culture and Role of Woman in Terrorism in Indonesia . Case Studies : Suicide Bombings in Surabaya and Sibolga," no. 5, pp. 873-876, 2019.

[10] E. Luiijf, "Definitions of Cyber Terrorism," in Cyber Crime and Cyber Terrorism Investigator's Handbook, 2014.

[11] D. Barnard-Wills and D. Ashenden, "Securing virtual space: Cyber war, cyber terror, and risk," Sp. Cult., 2012.

[12] R. Torok, “"Make A Bomb In Your Mums Kitchen’: Cyber Recruiting And Socialisation of 'White Moors' and Home Grown Jihadists," Proc. 1st Aust. Count. Terror. Conf., 2010.

[13] A. Halafoff, K. Lam, G. Bouma, and K. Lam, "Worldviews education : cosmopolitan peacebuilding and preventing violent extremism Worldviews education : cosmopolitan peacebuilding and," J. Beliefs Values, vol. 40, no. 3, pp. 381-395, 2019.

[14] C. Nwangwu and C. Ezeibe, "Femininity is not Inferiority : women-led civil society organizations and ' countering violent extremism' in Nigeria," Int. Fem. J. Polit., vol. 0, no. 0, pp. 1-26, 2019.

[15] W. Stephens, S. Sieckelinck, and H. Boutellier, "Preventing Violent Extremism: A Review of the Literature," Stud. Confl. Terror., vol. 0, no. 0, pp. 1-16, 2018. 
